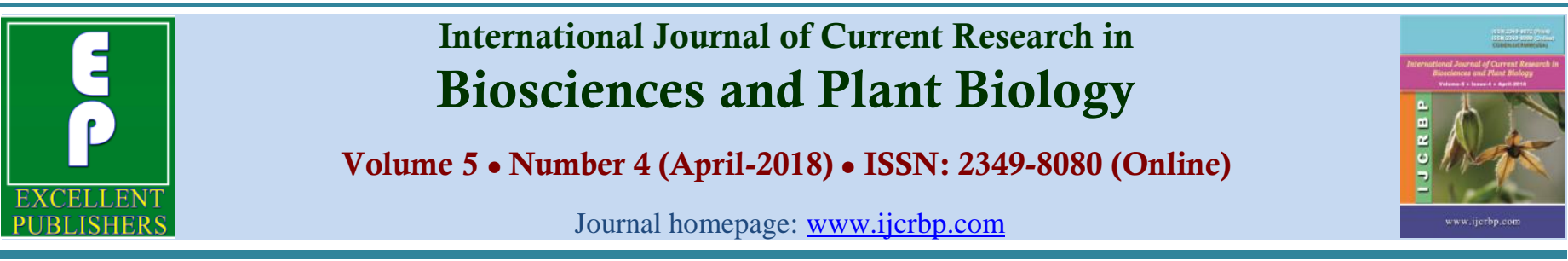

\title{
Comparative Study of the Cytotoxicity of 70\% Ethanolic Extracts of Pitadeniastrum africanum Hook (Fabaceae) and Hunteria eburnea Pichon (Apocynaceae) on HFF Cells (Human Foreskin Fibroblasts)
}

\author{
KANGA Yao ${ }^{1 *}$, CAMARA Djeneb1, COULIBALY Kiyinlma², \\ BENE Kouadio $^{1}$ and ZIRIHI Guédé Noël ${ }^{1}$
}

\author{
1Botany Laboratory, Training and Research Unit Biosciences, 22 BP 582 Abidjan 22, \\ Felix Houphouet-Boigny University, Cote d'Ivoire \\ 2UFR Biological Sciences, Plant Production Department, Peleforo Gon Coulibaly University, \\ B.P. 1328 Korhogo, Ivory Coast \\ ${ }^{*}$ Corresponding author.
}

\begin{tabular}{|c|c|}
\hline Article Info & A B S \\
\hline $\begin{array}{l}\text { Date of Acceptan } \\
31 \text { March } 2018 \\
\text { Date of Publicati } \\
06 \text { April } 2018\end{array}$ & \multirow{3}{*}{$\begin{array}{l}\text { Piptadeniastrum africanum and Hunteria eburnea are two plants that are recurrently } \\
\text { mentioned in the treatment of several skin diseases in the Upper Sassandra Region. In } \\
\text { order to better understand the mode of action of these two plants on skin cells, a } \\
\text { comparative study of the cytotoxicity of ethanolic extracts in vitro was performed on } \\
\text { HFF (Human Foreskin Fibroblasts) cells. The Mosman method was used to evaluate } \\
\text { the cytotoxic activity of the ethanolic extracts of both plants. The cytotoxicity test } \\
\text { performed in vitro on HFF cells revealed not cytotoxic effects of both plants on human } \\
\text { cells at concentrations of } 125 \text { to } 1000 \mu \mathrm{g} / \mathrm{mL} \text {. The different viability rates of the two } \\
\text { ethanolic extracts were strictly greater than } 30 \% \text {. All these results demonstrate a safety } \\
\text { of use of these two plants in the traditional treatment of various skin diseases. }\end{array}$} \\
\hline Keywords & \\
\hline & \\
\hline
\end{tabular}

\section{Introduction}

Infectious diseases account for $1 / 3$ of global mortality and $45 \%$ of deaths in developing countries because of the multi-resistance phenomenon (Simporé et al., 2006). In Ivory Coast, this rate is between 50 and 60\% (OMS, 2007). The excessive and uncontrolled use of antibiotics has resulted in an increasing resistance of germs to the synthetic molecules currently available. This has made it even more difficult to care for people with infectious diseases such as suppuration, chronic wounds and others (Yao, 2013). Faced with this threat, the search for new molecules has become a necessity for the scientific world. In this quest, medicinal plants remain the main reservoir that is used by more than $80 \%$ of populations in developing countries for their health care (OMS, 2003). It is in this perspective that 
this study aims to evaluate and compare the cytotoxic activity of two medicinal plants Piptadeniastrum africanum and Hunteria eburnea on HFFcells. These two plants were selected in an ethnobotanical survey carried out in the HautSassandra Region (Ivory Coast) for their frequency of use in cutaneous pathologies.

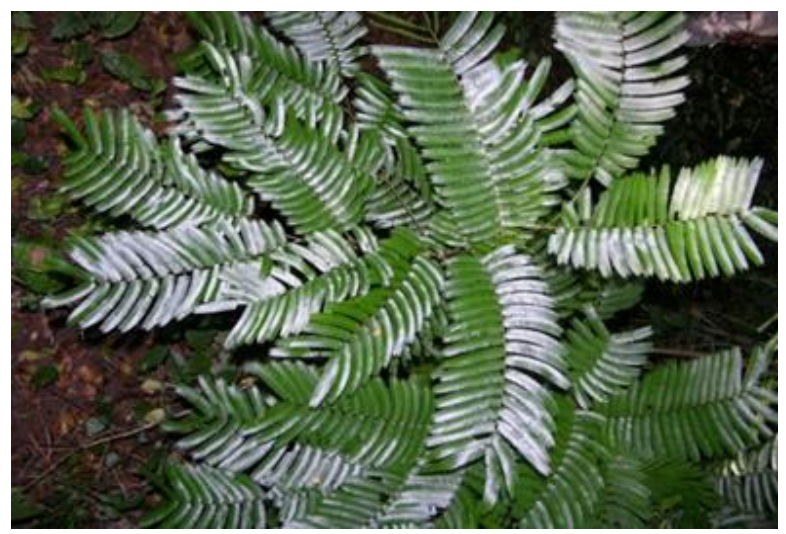

A: Leafy branch

\section{Materials and methods}

\section{Plant material}

It consists of the stem barks of Piptadeniastrum africanum Hook. (Fabaceae) and Hunteria eburnea Pichon (Apocynaceae) (Figs. 1 and 2).

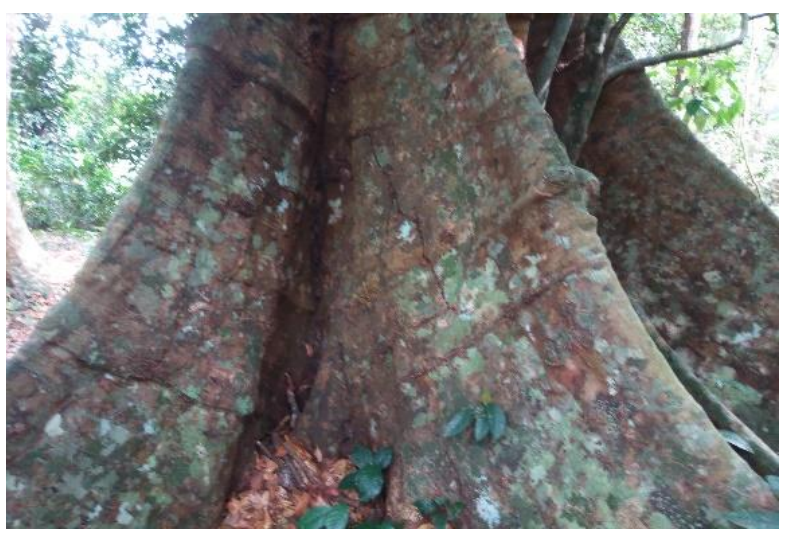

B: Buttresses

Fig. 1: Piptadeniastrum africanum Hook (Fabaceae).

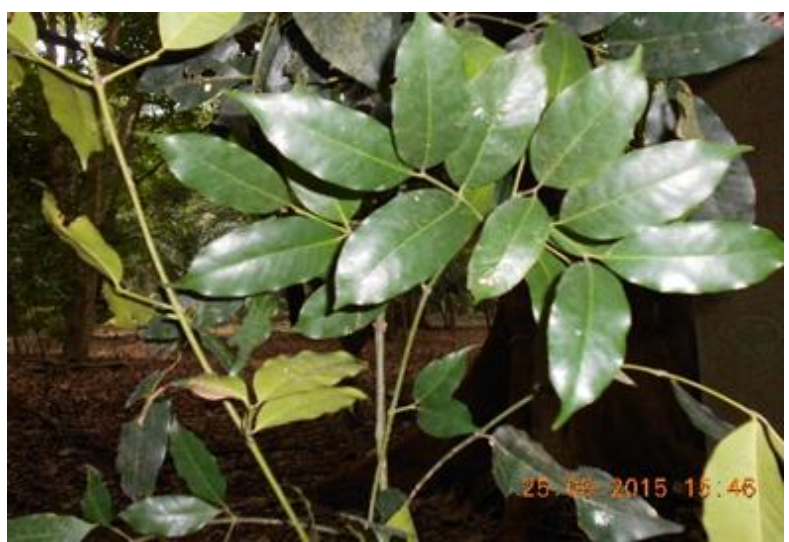

A: Leafy twig

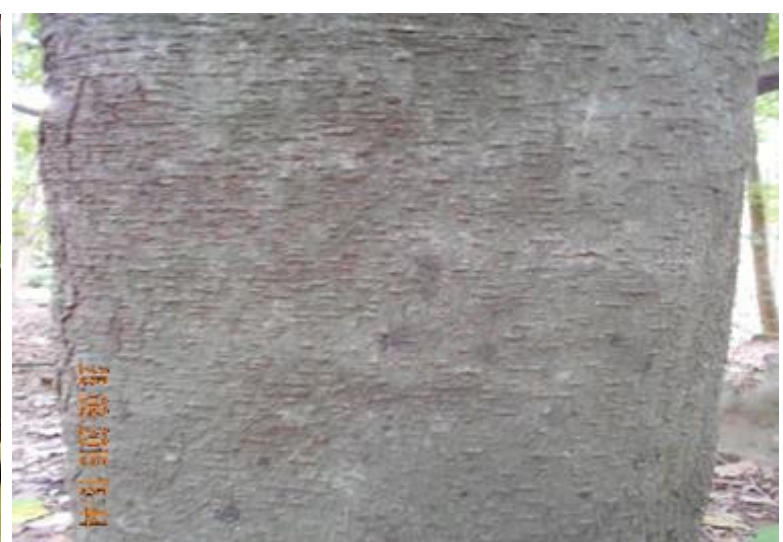

B: Bark of the trunk

Fig. 2: Hunteria eburnea Pichon (Apocynaceae).

\section{Cellular material}

The cellular support consisted of human HFF (Human Foreskin Fibroblasts) cells. These are human cells that testify to the toxic activity of an extract. They have the particularity of forming a cell layer after several days of culture (96 hours - 4 days), it is said that they are confluent, they stop dividing by contact inhibition. When these cells are in culture for only 24 hours, they are in a state of mitosis (or dividing cells). These HFF cells are cultured at $37^{\circ} \mathrm{C}$ under $5 \% \mathrm{CO}_{2}$ in $\mathrm{D} 10$ medium (Gibco, supplemented with fetal calf serum $10 \%$, glutamine $1 \%$, penicillin $50 \quad \mathrm{U}^{\mathrm{ml}}{ }^{-1}$ and streptomycin $50 \mathrm{ug} / \mathrm{uL})$.

\section{Collection of barks of plants}

The barks of Piptadeniastrum africanum and Hunteria eburnea were harvested in August 2015 in the Upper Sassandra Region (Ivory Coast). The samples of these two plants have been identified at 
the National Floristic Center of the UFR Biosciences of Félix Houphouët Boigny University.

\section{Preparation of plant extracts}

After harvest, the barks were cleared of impurities, dried in the shade and in an air-conditioned laboratory for one week and then pulverized with an electric grinder. The fine powders obtained were stored in glass jars to prevent mold.

\section{Total Aqueous Extract (ETA)}

The dried barks of each plant were pulverized by a Moulinex type electric grinder. The powder obtained was used to prepare the various extracts. Thus ETA was obtained according to the following method (Zirihi et al., 2003, Bagré et al., 2006): One hundred grams of plant powder are extracted with distilled water by grinding in a mixer (Blender) three times three minutes at room temperature. The homogenate obtained is drained in a square of fabric and then filtered successively four times on hydrophilic cotton and then on Wattman paper (3 $\mathrm{mm})$. The filtrate is evaporated at $50^{\circ} \mathrm{C}$ using a venticell ${ }^{\circledR}$ type oven. The dry evaporate obtained constitutes the aqueous total extract (ETA).

\section{Ethanol extract 70\% (EE70\%)}

The $70 \%$ ethanolic extract comes from the total aqueous extract, according to the following method (Zirihi et al., 2003): Ten grams (10 g) of ETA are dissolved in $100 \mathrm{ml}$ of an ethanol solution $70 \%$ thenhomogenized in a Blender. After decantation in a separatory funnel, the supernatant is collected, filtered through cotton to remove any residue and dried in an oven $\left(50^{\circ} \mathrm{C}\right)$. The powder obtained constitutes $70 \%$ ethanolic extract (EE70\%).

\section{Cytotoxicity test}

The toxicity tests were carried out at LAPM (Laboratory Adaptation and Pathogenesis of Microorganisms) in Grenoble, France. To measure the toxicity of the ethanolic extract, the Human Foreskin Fibroblasts (HFF) cells were seeded in 96- well plates (CellStar) at 3000 to 5000 cells per well in $100 \mu \mathrm{l}$ of D10 medium. These cells are kept in culture for 24 hours (dividing cells) or 96 hours (confluent cells). Subsequently they were exposed for 24 hours at different concentrations (0-1000 Yg $/ \mathrm{ml}$ ) plant extract solubilized in PBS buffer. This was done in triplicate.

Viability was determined using 3- (4,5dimethylthiazol-2-yl) -2,5-diphenyl tetrazolium bromide (MTT). The tetrazolium ring it contains is reduced in formazan by the mitochondrial succinate dehydrogenase of metabolically active cells, which precipitates and gives a violet color. The amount of precipitate formed is proportional to the number of living cells. In each well, MTT is added at a concentration of $500 \mu \mathrm{g} / \mathrm{ml}$ and incubated for 3 hours at $37^{\circ} \mathrm{C}$. The formazan crystals are solubilized in dimethyl sulfoxide (DMSO) $10 \mathrm{mM}$. The measurement of the optical density at $544 \mathrm{~nm}$ was made using a Safir Spectrophotometer (Tecan); this measurement of absorbance will determine the relative amount of living and metabolically active cells (Mosman, 1983).

Viability rate $=($ Abs544 nm extract $/$ Abs544 nm control $) \times 100$

\section{Results}

Cytotoxicity test of $70 \%$ ethanolic extract of Hunteria eburnea

The ethanolic extract of Hunteria eburnea did not have any toxic effect on the cells. On the other hand, when the cells are in division, as light decrease in the viability rate has been noted. At $1000 \mu \mathrm{g} / \mathrm{mL}$, the percentage of viability was $101 \%$ for confluent cells and dividing cells (Fig. 3).

\section{Cytotoxicity test of $70 \%$ ethanolic extract of} Piptadeniastrum africanum

The analysis of the results showed that the percentage of viability of human cells increase progressively as a function of the concentrations of plant extracts. Statistical analysis of variance shows that there is a highly significant difference 
$(p<0.001)$ between confluent cells and dividing cells. At $1000 \mu \mathrm{g} / \mathrm{mL}$, the percentage of viability is $193 \%$ for confluent cells and $215 \%$ for dividing cells (Fig. 4). This shows that Piptadeniastrum africanum is not toxic, but accelerates cell division (mitogenic effect).

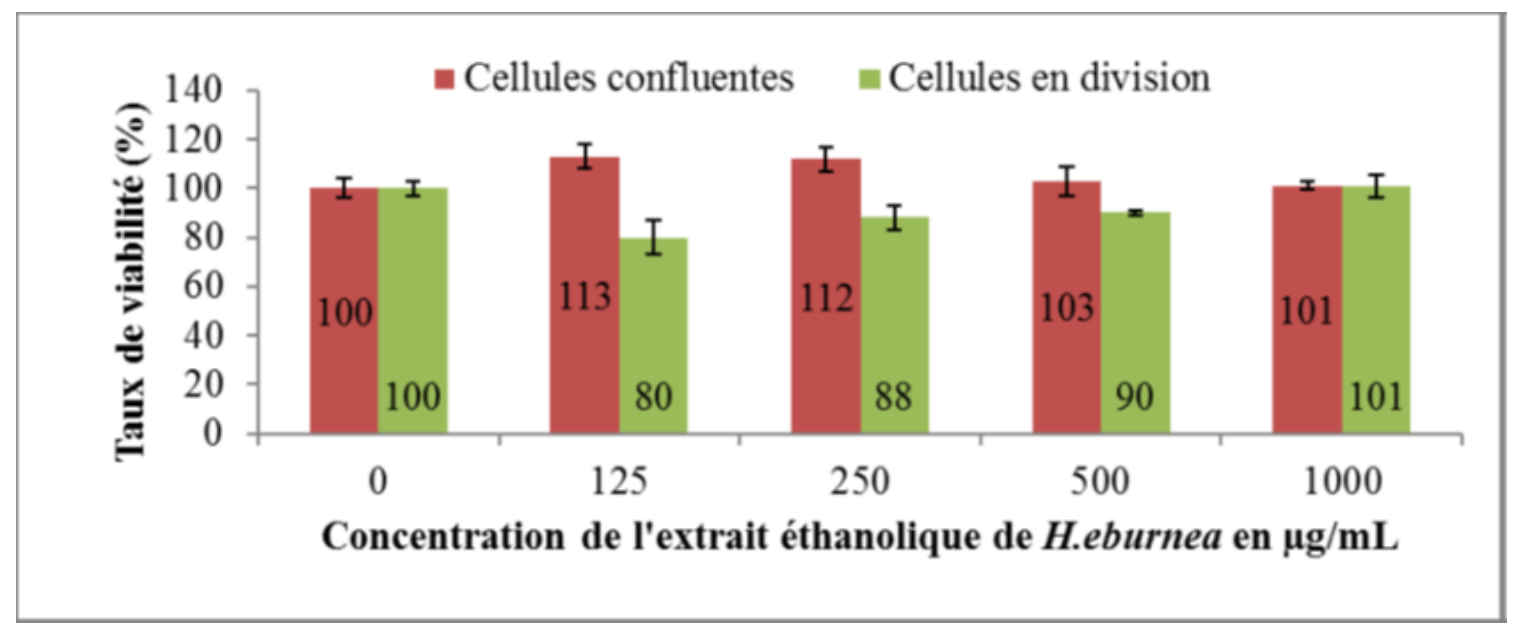

Fig. 3: Viability of HFF cells in the presence of ethanolic extract of Hunteria eburnea.

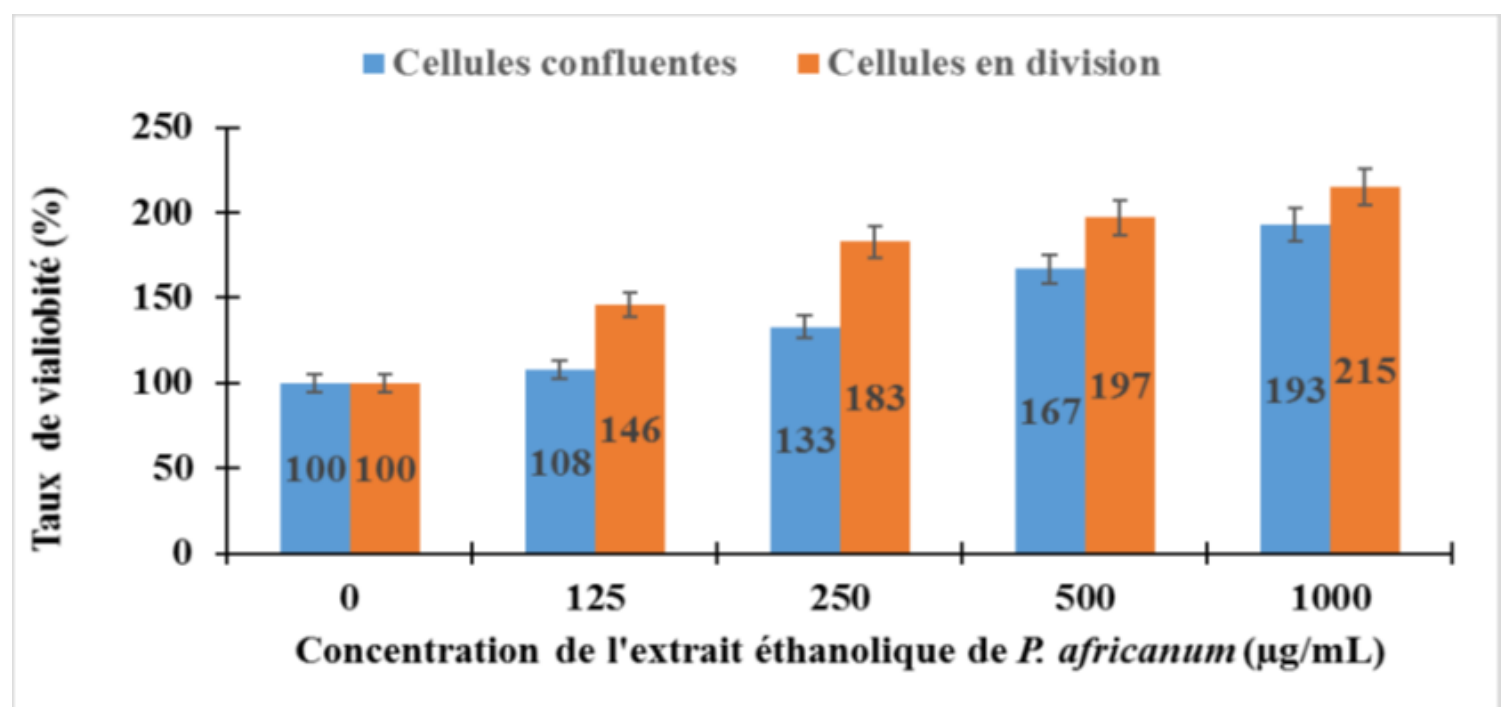

Fig. 4: Viability of HFF cells in the presence of ethanolic extract of Piptadeniastrum africanum

\section{Discussion}

The results of the cytotoxic tests carried out on the HFF cells have shown that the ethanolic extracts of Piptadeniastrum africanum and Hunteria eburnea are not toxic on the human HFF cells. Indeed, according to Bené (2017), when the viability of an extract is strictly greater than $30 \%$ the extract is declared not cytotoxic. But the ethanolic extract of Piptadeniastrum africanum showed a mitogenic effect on dividing HFFcells. This mitogenic effect is thought to be due to a chemical compound that acts as a growth factor favoring the multiplication of HFF cells (Camara et al., 2016). Our results are consistent with those of Yapo et al. (2016) who also showed that the leaves of Mallotus oppositifolius (Geiseler) Müller. Arg. (Euphorbiaceae) used in traditional medium in the Great Bridges Region (Ivory Coast) had no cytotoxic effects on HFF cells. The results of the cytotoxicity of the $70 \%$ ethanolic extract of Hunteria eburnea compared to those of Bourobou et al. (2015) carried out on two plant species of the family Apocynaceae confirm the results of this study. Indeed, this author has shown 
that Alstonia boonei and Alstonia congensis have very low toxicity on human embryonic cells (MRC-5). That said, the use of the bark of these two plants in traditional medicine poses no risk in terms of skin cell toxicity. This could justify the use of the stem bark of these plants in traditional environment.

\section{Conclusion}

The comparative study of the cytotoxic effect of the ethanolic extract of Hunteria eburnea and the aqueous and ethanolic extract of Piptadeniastrum africanum revealed that the extracts of both plants are not toxic to human HFF cells. These results may partly explain the safe use of extracts from these two plants in a traditional environment.

\section{Conflict of interest statement}

Authors declare that they have no conflict of interest.

\section{Acknowledgement}

The authors thank the Laboratory Adaptation and Pathogenesis of Microorganisms (LAPM) of Grenoble in France, where cytotoxicity studies were carried out and the traditional health practitioners of the Haut-Sassandra Region.

\section{References}

Bagré, I., Bahi, C., Méité, S., Djaman, A. J., Guédé, G.F., 2006. Évaluation et amélioration in vitro de l'activité antifongique de Morinda morindoides (Baker) Milne-Redh (Rubiaceae) sur Cryptococcus neoformans, un champignon responsable de mycose humaine. J Sci. Pharm. Biol. 7, 37-46.

Bené, K., 2017. Plantes médicinales du Gontougo (district du Zanzan, Côte d'Ivoire) : inventaire, évaluation des activités pharmacologiques de deux plantes et formulation d'une pommade dermatologique à partir de l'extrait hydroalcoolique de Bersama abyssinica fresen. (melianthaceae). Thèse de Unique de
Botanique, UFR Biosciences; Université Félix Houphouët-Boigny (Côte d'Ivoire). 200 p.

Bourobou, B.H.P., Lekana-Douki, J.B., ToureNdouo, F., Bhattacharya, D., 2015. Etude comparative de la toxicité des extraits de deux espèces d'Alstonia (Apocynaceae) utilisées traditionel-lement au Gabon pour soigner le paludisme. Pharma Med. Tradition. Afr. 17(2), 1-8.

Camara, D., Bené, K., Gnahoue, G., Fofié, N.B.Y, Zirihi, G.N., 2016. Etude ethnobotanique, évaluation de l'activité antifongique sur Candida albicans et de la toxicité sur des cellules HFF de Bersama abyssinica (Fresen.), une plante de la pharmacopée ivoirienne. Europ. Scient. J. 12(3), 171-185.

Mosman, T., 1983. Rapid colorimetric assay for cellular growth and survival: Application to proliferation and cytotoxicity assay. J. Immunol. Meth. 65, 55-63.

OMS, 2003. Médicaments essentiels et politiques pharmaceutiques: donner un soutien au pays pour produire le manque d'accès aux médicaments. Genève: OMS (rapport annuel 2002) $20 \mathrm{p}$.

OMS, 2007. Maladies transmissibles, profil epidemiologique (Cote d'Ivoire). [online] http://whqlibdoc.int/hq/2010/WHO_HSE_GAR _DCE_2010.3.fre.pdf. (juin 2016).

Simpore, J., Zeba, B., Karou, D., Ilboudo, D., Esposito, M., D'agata, A., Pignatelli, S., Nacoulma, O.G., Musumeci, S., 2006. Bacterial epidemiology and emergence of multi-drugresistance in Burkina Faso. Microb. DrugResist. 5(64), 38-42.

Yao, A.C., 2013. Investigations pour un développement potentiel de nouveaux médicaments antimicrobiens à partir des extraits végétaux, inhibiteurs de la voie du méthyl erythritol phosphate (MEP), une des voies de biosynthèse des isoprenoïdes. DEA de Botanique, UFR Biosciences; Université Félix Houphouët-Boigny. 58 p.

Yapo, Y. C. V., Konkon, G., Coulibaly, K., Camara, D., Zirihi, G. N., 2016. Etude botanique, évaluation de l'activité antifongique sur la croissance in vitro de Candida albicans et 
de la toxicité sur des cellules HFF de feuilles de Mallotus oppositifolius (Geiseler) Müller. Arg (Euphorbiaceae). J. Anim. Plant Sci. 28(1), 4330-4339.

Zirihi, G. N., Kra, A. M., Guédé-Guina, F., 2003.
Évaluation de l'activité antifongique de Microglossa pyrifolia (Lamarck) O. Kunze (Asteraceae) <<PYMI > sur la croissance in vitro de Candida albicans. Rev. Med. Pharm. Afr. 17, 11-18.

\section{How to cite this article:}

Kanga, Y., Camara, D., Coulibaly, K., Bene, K., Zirihi, G. N., 2018. Comparative study of the cytotoxicity of $70 \%$ ethanolic extracts of Pitadeniastrum africanum Hook (Fabaceae) and Hunteria eburnea Pichon (Apocynaceae) on HFF Cells (Human Foreskin Fibroblasts). Int. J. Curr. Res. Biosci. Plant Biol. 5(4), 4752. doi: https://doi.org/10.20546/ijcrbp.2018.504.007 